\title{
SUCKLING CALVES PERFORMANCE AND IMMUNE STATUS AS AFFECTED BY LACTOCOCCUS LACTIS AS A PROBIOTIC SOURCE
}

\author{
U.A. Nayel, G.A. Baraghit, B.M. Ahmed and M.A. Elmeshtawy \\ Department of Animal Production, Faculty of Agriculture, Menoufia University, \\ Menoufia, Egypt.
}

Received: May. 28, 2019

Accepted: Jul. 27,2019

\begin{abstract}
This study sought to investigate the effects of Probiotic, Lactococcus lactis bacteria (LC.) on growth performance, nutrients digestibilities, diarrhea incidence and immune status of buffalo calves. Thirteen suckling buffalo calves were divided into two groups according to their body weight, age and sex (T1- Control (No LC. supplementation, T2- $4 \mathrm{~g}$ LC. Per calf in breast milk). The Calves were fed $10 \%$ of their body weight fresh milk 2 times daily and provided calf starter and clover hay to meet their requirements of DM according to Kearl (1982). Calves body weight was recorded at the start of the experiment and thereafter regularly at 10 days interval. Diarrhea occurrence also faecal scores have been detected. After completion of the feeding trial, three animals per treatment were used in a metabolism trial. We obtained blood samples at the end of the study from each calf through jugular vein puncture. Obtained results showed significant $(P<0.5)$ increase in roughage, concentrate and total $D M$ intakes with calves fed LC-supplemented than the control (T1) group during the periods of $P 3, P 4$ and $P 5$. Supplementation of LC. $L$ to calves in T2 group had showed an increase in body weight than T1- group; the increase in total gain and average daily gain (ADG) was significant $(P<0.05), C P, C F, E E$ and NFE digestion coefficients keep on the same trend. Diarrhea occurred on $T 1$ calves were more than $T 2$ calves, and the duration of diarrhea at the same time was longer in control calves than treated calves. The number of E.coli in feces was more in control calves than treated calves. Immunological parameters (IgA, IgG and interleukin 2) have been increased in treated calves than control with no significant difference $(P>0.05)$.
\end{abstract}

Key words: Probiotic, Lactococcus lactis, Performance, immune, calves.

\section{INTRODUCTION}

The young calf encounters potentially stressful situations in its first few months of life including transportation, dehorning, castration, weaning, and commingling. The risk of disease and the immune system repression can be increased by stress in the presence of a pathogen (Salak-Johnson and McGlone, 2014). Average daily gain and leukocyte function have been decreased in young calves which lives in group housing system, the risk of bovine respiratory disease increased in these calves (Hulbert and Ballou, 2012).
Consequently, research specifically involving methods to aid calves in maintaining health and growth through stressful situations, such as commingling, may be beneficial.

Recently, probiotic expression of lactic acid bacteria has been emphasized. But, few studies on the probiotic state of Lactococcus strains since they are traditionally not reasoned to be elemental inhabitants of the human gastrointestinal tract (Teuber et al. 1992). Still, various activity showed the possibility of the proximity of Lactococcus strains in the 
human flora or animal gastrointestinal tract (Gruzza et al. 1992; Grahn et al. 1994; Klijn et al. 1995b). The present work was carried out in order to investigate the effect of Lactococcus lactis as a probiotic source on the growth performance, digestibility, immunity state, diarrhea incidences and GIT pathogenic microorganism of young calves.

\section{MATERIALS AND METHODS}

This study was conducted at the Experimental Station and Nutrition Laboratory, Animal Production Department, Faculty of Agriculture, Menoufia University (Shebin El-Kom) in order to investigate the effect of lactococcus lactis as a probiotic source on the performance of young calves. Thirteen suckling buffalo calves were divided into two groups according to their live body weight, seven calves in treated group and six calves in control group. Daily feed allowance was changed quantitatively according to the change in body weight. Feed was offered twice daily at 8:00 and 16.00 hr. Fresh water was getable at all times. Calves were fed $10 \%$ of their body weight fresh milk 2 times daily and provided calf starter and clover hay to meet their requirements of DM according to (Kearl (1982). Two experimental rations were prepared: Ration 1 (R1): Control (No probiotic supplementation). Ration 2(R2): Control + 4g probiotic (Lactocoocus lactis)/calf. (According to manufacturer's instructions)

\section{Specification and analysis of} probiotic:

** Culture identify is confirmed at the genus/species level based on $16 \mathrm{~s}$ rRNA sequencing

Product name: Lactococcus Lactis Type: LLL-G25-110

Batch No.: 20170207

Shelf life: 24 months

\begin{tabular}{|c|c|c|}
\hline Items & Specification & Results \\
\hline Appearance & fluffy light yellow powder & complies \\
\hline \multicolumn{3}{|c|}{ no off-flavor, no visible impurity } \\
\hline Water & $\leq 8 \%$ & $1.4 \%$ \\
\hline \multicolumn{2}{|c|}{$\begin{array}{l}\text { Content of activity } \\
1.5 \times 10^{10} \mathrm{cfu} / \mathrm{g}\end{array}$} & fu/g \\
\hline \multicolumn{2}{|c|}{ Non lactic acid bacteria } & $<10$ cfu/g \\
\hline Coliforms & $\leq 10 \mathrm{cfu} / \mathrm{g}$ & $<10$ cfu/g \\
\hline Mold \& Yeas & $\leq 10 \mathrm{cfu} / \mathrm{g}$ & $<10$ cfu/g \\
\hline \multicolumn{2}{|c|}{ Pathogenic bacteria } & negative \\
\hline Lead(Pb) & $\leq 1.0 \mathrm{mg} / \mathrm{kg}$ & $<1.0 \mathrm{mg} / \mathrm{kg}$ \\
\hline Total Arsenic & $\leq 0.5 \mathrm{mg} / \mathrm{kg}$ & $<0.5 \mathrm{mg} / \mathrm{kg}$ \\
\hline
\end{tabular}

The complete chemical composition of the experimental rations is shown in Table (1).

Table 1: Chemical composition (\%) of the experimental rations.

\begin{tabular}{|c|c|c|c|c|c|c|c|}
\hline Item & DM & OM & CP & EE & NFE & CF & Ash \\
\hline $\begin{array}{c}\text { Concentrate } \\
\text { (CS) }\end{array}$ & 91.5 & 95 & 19.2 & 7.1 & 64.7 & 4 & 5 \\
\hline $\begin{array}{c}\text { Forage } \\
\text { Clover hay }\end{array}$ & 88.6 & 91.7 & 10.5 & 4 & 48.2 & 29 & 8.3 \\
\hline
\end{tabular}

DM, dry matter; OM, organic matter; $C P$, crude protein; $E E$, ether extract; NFE, nitrogen-free extract; CF, crude fiber. Calf Starter (CS): corn $65 \%$, wheat bran $6 \%$, soya bean meal $26 \%$, $\mathrm{CacO}_{3}$ $1.6 \%$, sodium chloride $1 \%$, minerals \&vitamins $4 \mathrm{~kg} /$ ton 
Body weights of calves in a 50-day trial were recorded at the beginning of the experiment and every ten days through the experimental period. Weighing was done at early morning before the calves were allowed to access feed and water. After completion of the feeding trial, three animals per treatment were used in a metabolism trial. After ten days as an adjustment period feces were collected from the experimental animals. Feces voided by each calf was weighed and recorded every day, mixed and $20 \%$ representative samples were taken and frozen at $-20^{\circ} \mathrm{C}$, also similar procedure was done for the provided feed and refusal samples collected. Offered feed samples, refusal and feces were integrated well and oven dried at $70^{\circ} \mathrm{C}$ for $48 \mathrm{~h}$. The dried samples of feeds and feces were ground through $1 \mathrm{~mm}$ strainer then stored for analysis. Nutrient digestibility (\%) was calculated as a difference between nutrient intake and nutrient voided in the feces divided by nutrient intake and the quotient multiplied by 100 .

Each day before feeding, calves were observed in their pens and fecal scores recorded according to the method of Larson et al. (1977). For fecal fluidity, scoring was done as follows: $1=$ normal, 2 = soft, $3=$ runny and $4=$ watery.

Rectum collected fecal samples were placed in sterile plastic tubes with led, then stored at $-20^{\circ} \mathrm{C}$ for determine of $\mathrm{E}$. coli enumeration. $E$. coli count procedure was done by using dilution plate count method. Three plates were inoculated with $1 \mathrm{ml}$ of the suitable dilution and poured on Eosin methylene blue (EMB) medium. The plates were incubated at 35$37^{\circ} \mathrm{C}$ for 24 hours for counting total coliform bacteria (Gue et al., 2006). Immunoglobulin A, immunoglobulin G and Interleukne 2 concentrations in serum were determined using single radio-immunodiffusion methods derived primarily from the works of Fahey and McKelvey (1965) and Mancini et al. (1965). These methods are specific for the quantitative determination of individual protein groups in biological fluids.

The obtained results were statistically analyzed using SPSS (Statistical Package for Social Sciences) program version 19, (2010). The following statistical model was applied:

Model:-

$$
Y_{i j}=\mu+T_{i}+e_{j}
$$

Where:

$Y_{i j}=$ the parameters under analysis.

$\mu=$ the overall mean.

$T_{i}=$ the treatment effect, $(i=1$ and 2$)$.

$\mathbf{e}_{\mathrm{j}}=$ the random error.

\section{RESULTS AND DISCUSSION \\ Effect of LC. Lactis (LC) on growth performance}

Many efforts have been focused around the therapeutic action of probiotics. Probiotics were first documented by Metchnikoff (1907) after his observance on the longevity of Bulgarian farmers who consumed great quantities of yogurt. He thought that hurtful organisms, detrimental to humans, were inhibited by beneficial bacteria existing in yogurt. Lilley and Stillwell (1965) described probiotics as materials secreted by one organism that encourages the growth of another. recently, probiotics have been described as microorganisms that have beneficial effects on the host animal by supplying intestinal microbial balance (Fuller, 1989). In the present study, it was found that supplementing calves' diet with LC significantly $(P<0.5)$ increased intakes of roughage, concentrate and total DM during the periods of P3, P4 and P5 (Table 2 and Fig. 1). 
U.A. Nayel, et al.,

Table 2: Feed intakes of calves as affected by LC supplementation

\begin{tabular}{|c|c|c|c|}
\hline \multirow{2}{*}{ Period } & \multicolumn{2}{|c|}{ Treatments* $(\mathrm{kg} / \mathrm{d})^{*}$ Sig } \\
\cline { 2 - 4 } & LC & Co & NS \\
\hline P1 & $2.44 \pm .076$ & $1.94 \pm .236$ & NS \\
\hline P2 & $2.64 \pm .093$ & $2.08 \pm .281$ & 0.05 \\
\hline P3 & $3.02 \pm .091$ & $2.21 \pm .305$ & 0.05 \\
\hline P4 & $3.14 \pm .093$ & $2.37 \pm .343$ & 0.05 \\
\hline P5 & $3.59 \pm .141$ & $2.63 \pm .411$ & 0.05 \\
\hline Roughage & $9.49 \pm .212$ & $7.40 \pm .981$ & 0.05 \\
\hline Concentrates & $5.35 \pm .330$ & $3.85 \pm .611$ & 0.05 \\
\hline Total DM Intake & $14.85 \pm .478$ & $11.25 \pm 1.576$ & \\
\hline
\end{tabular}

${ }^{*}$ Co, Control (un-supplemented); LC, treated ration (supplemented with LC. Lactis)

P1 (period: 10 days after experimental beginning. P2,P3,P4,P5 :10 days interval )

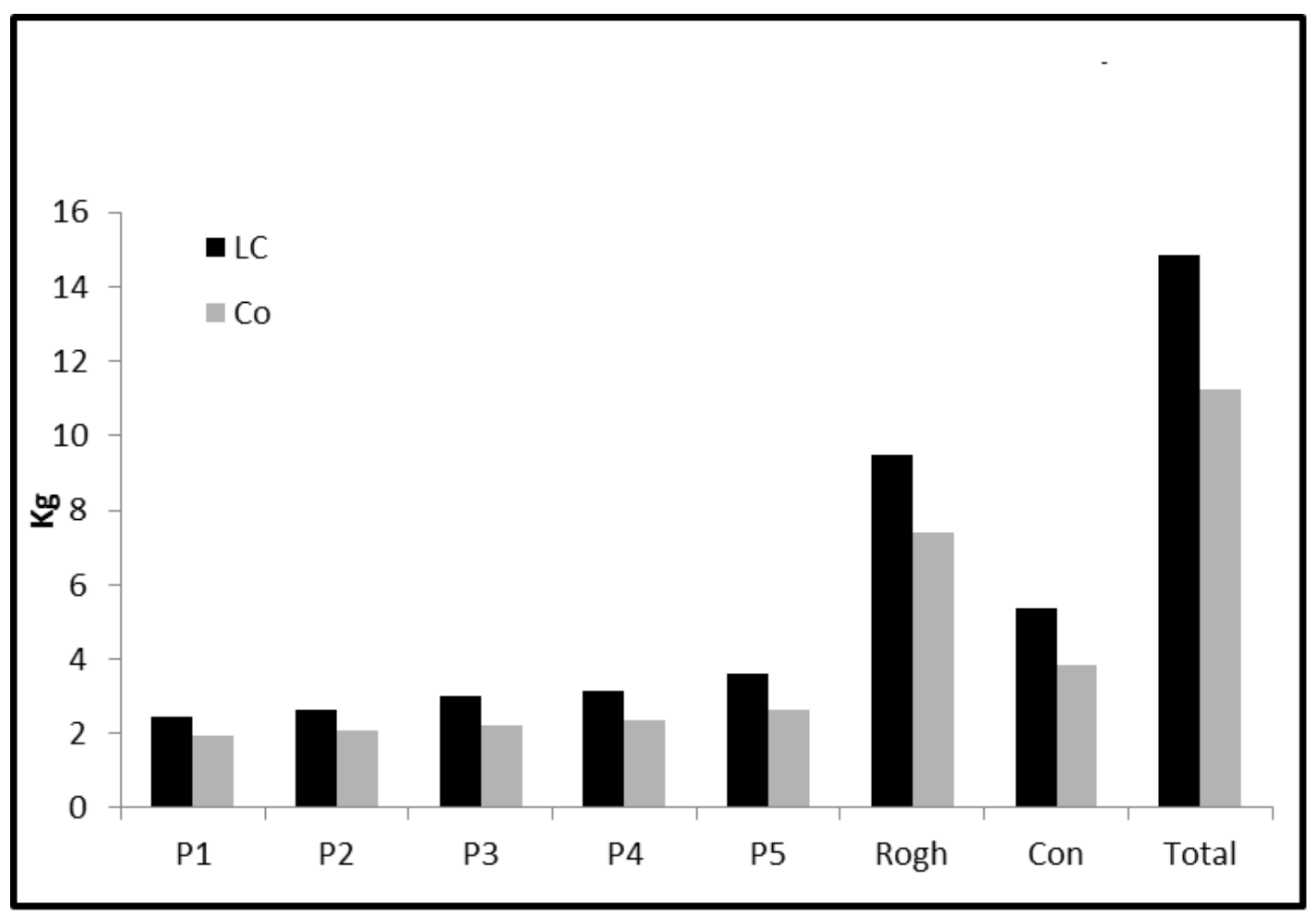

Fig. 1: Feed intake of calves as affected by LC. 
Table (3) showed an increase in body weight in LC-group than Co- group; the increase in total gain and ADG was significant $(P<0.05)$. The results were illuminated in Figs 2, 3 and 4.

Table 3: Change in body weight of calves fed the experimental rations Mean \pm SE

\begin{tabular}{|c|c|c|c|}
\hline \multirow{2}{*}{ Period } & \multicolumn{2}{|c|}{ Treatments* $^{*}(\mathrm{~kg})$} & \multirow{2}{*}{ Sig } \\
\cline { 2 - 3 } & LC & Co & NS \\
\hline IBW & $74.42 \pm 6.27$ & $73.16 \pm 4.99$ & NS \\
\hline P1 & $80.14 \pm 6.85$ & $77.16 \pm 6.00$ & NS \\
\hline P2 & $87.00 \pm 7.90$ & $80.83 \pm 6.72$ & NS \\
\hline P3 & $91.00 \pm 8.07$ & $85.16 \pm 7.55$ & NS \\
\hline P4 & $99.71 \pm 8.87$ & $90.66 \pm 9.24$ & NS \\
\hline P5 & $107.85 \pm 9.30$ & $95.66 \pm 9.86$ & 0.05 \\
\hline Total gain & $33.42 \pm 3.20$ & $22.50 \pm 4.99$ & 0.05 \\
\hline ADG & $0.64 \pm 0.061$ & $0.43 \pm 0.096$ & \\
\hline
\end{tabular}

${ }^{*}$ Co, Control (un-supplemented); LC, treated ration (supplemented with LC. Lactis) IBW, initial body weight; P (period: 10d); ADG, average daily gain

P1 (period: 10 days after experimental beginning. P2,P3,P4,P5 :10 days interval )

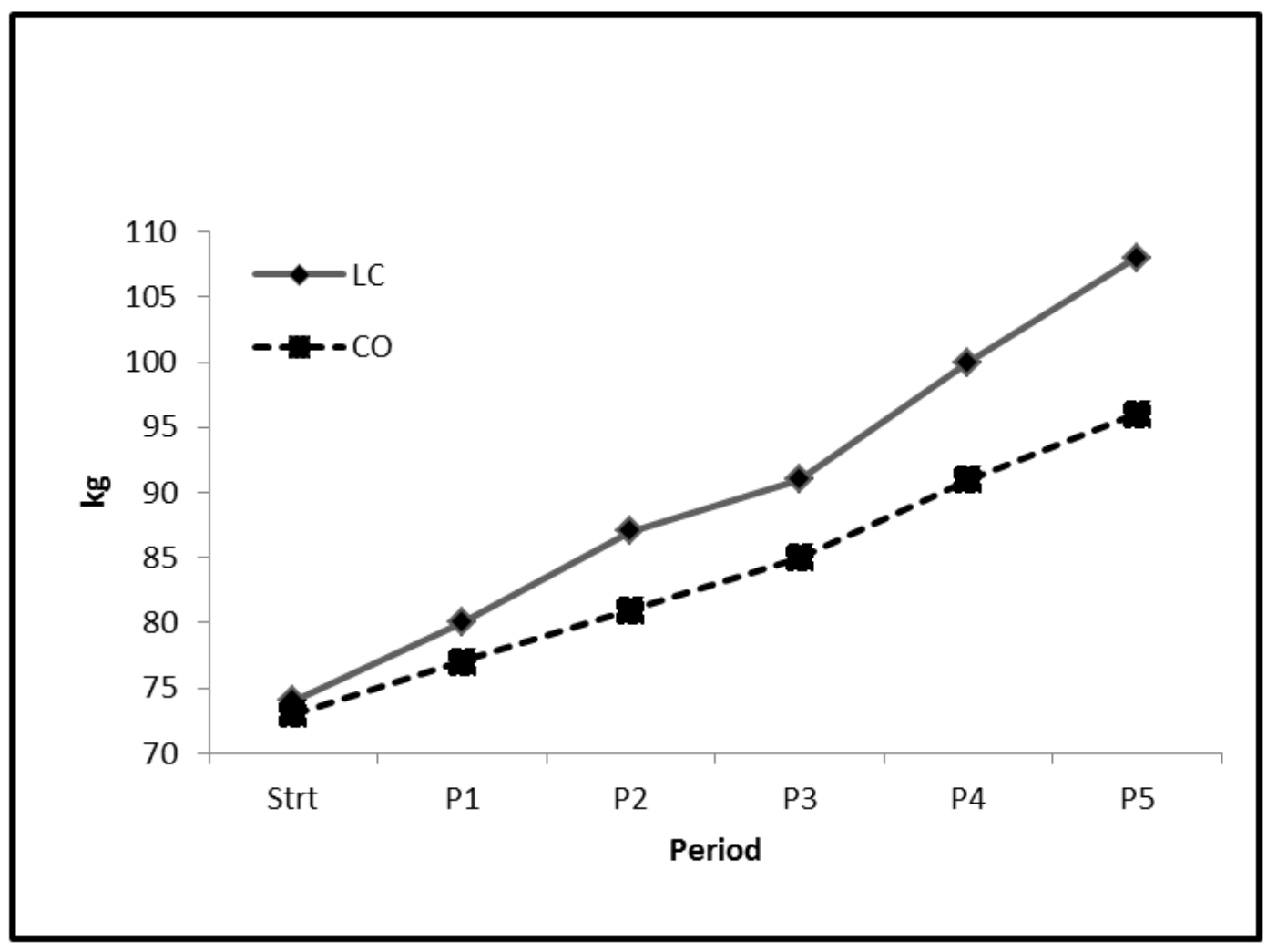

Fig. 2: Change in body weight of calves as affected by LC. 


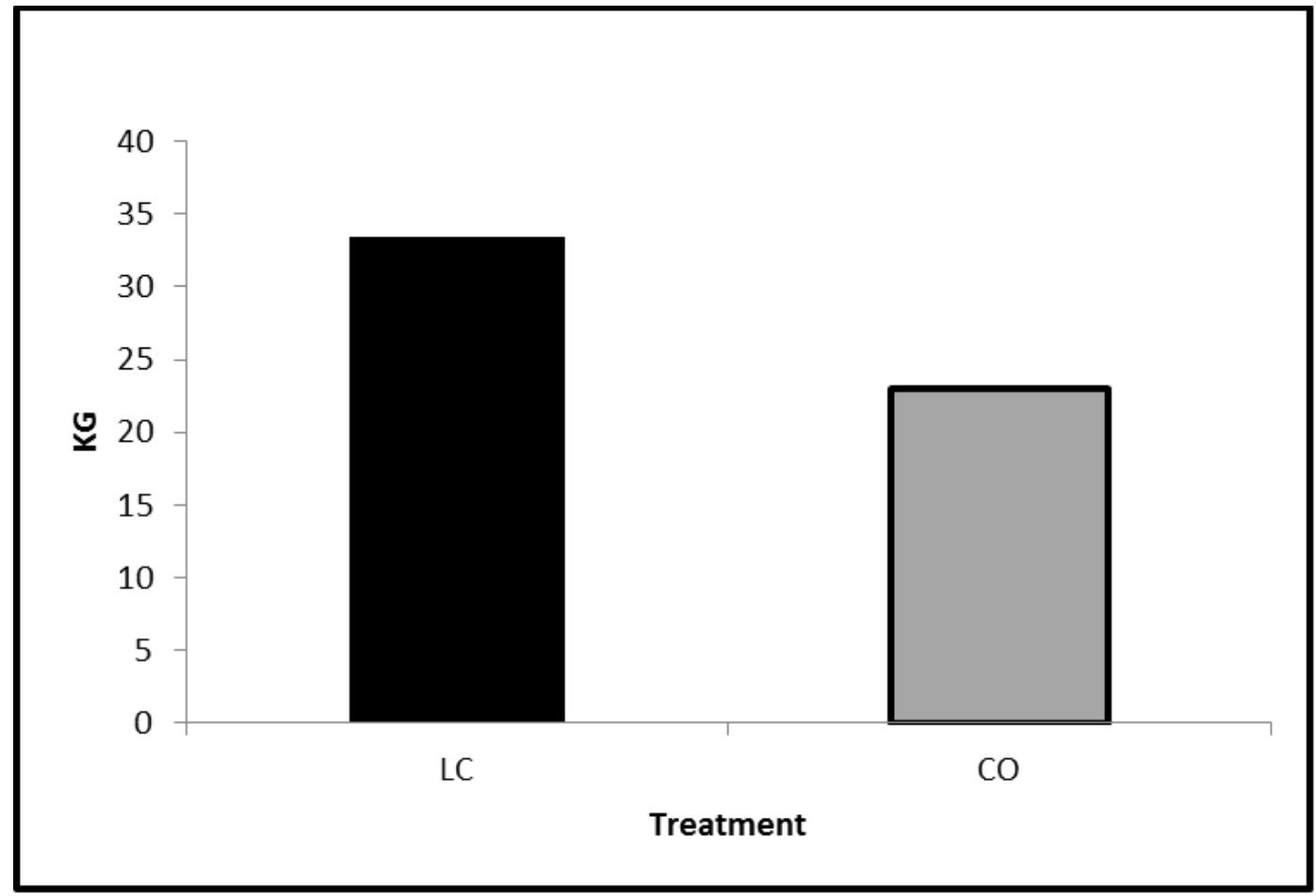

Fig. 3: Total gain of calves as affected by LC.

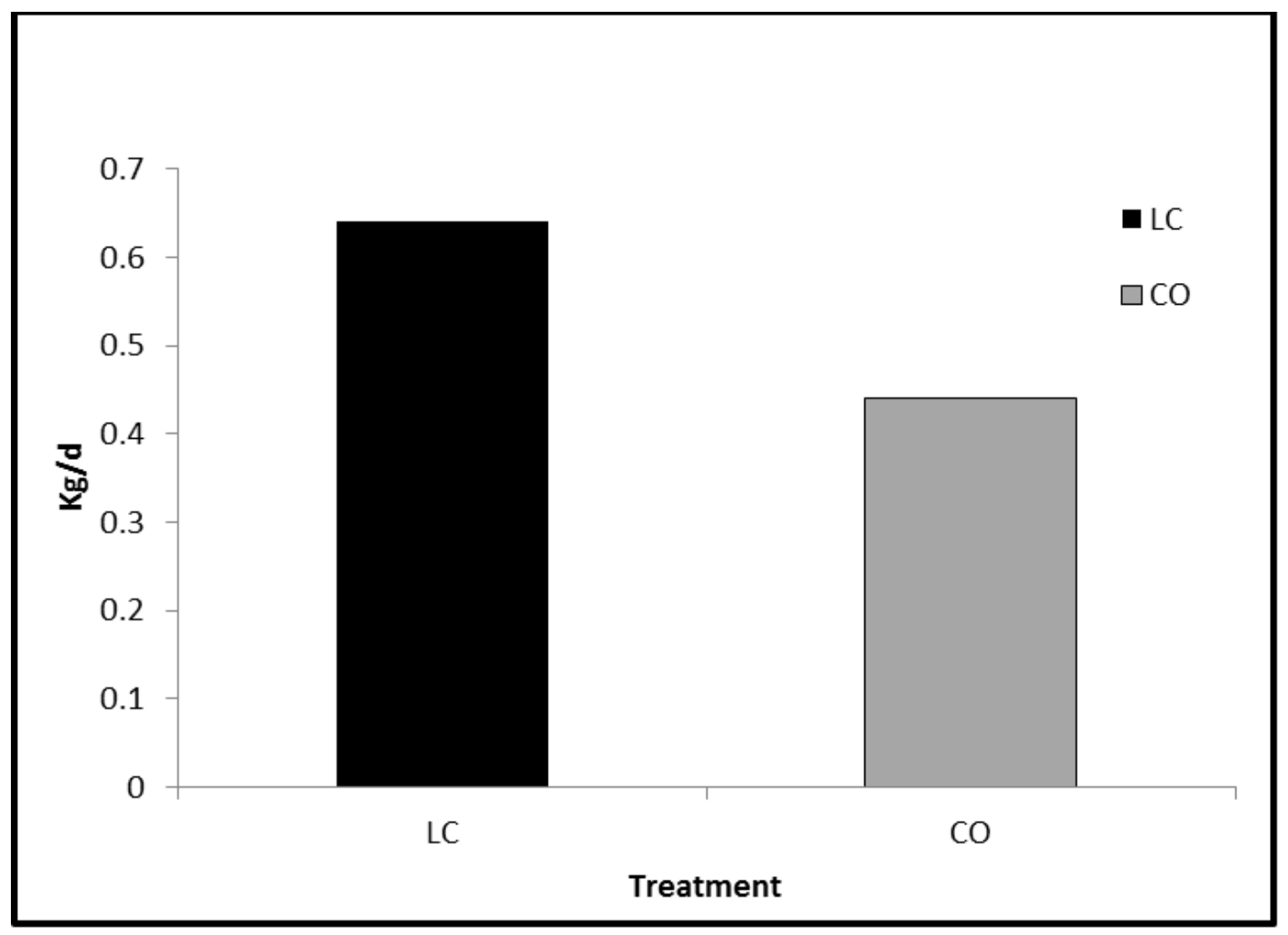

Fig. 4: ADG of calves as affected by LC. 
Numerous investigators reported a positive effect of probiotic supplementation on nutrient intake, bodyweight gain and feed conversion rate in small ruminants (Antunovic et al., 2006 and Whitley et al., 2009).

It has been stated that influence of probiotics in animals performance may differ, as supplementation can enhance feed intake (Abd El-Ghani, 2004; Antunovic et al., 2005; Desnoyers et al., 2009), feed conversion ratio (Khalid et al. 2011) or bodyweight gain (Jang et al., 2009; Hussein, 2014). Haddad and Goussous (2005) reported increase in body weight of Awassi lambs which supplemented with yeast culture compared to controls (266 versus $212 \mathrm{~g}$ daily). The administration of probiotic to dairy calves (Le et al., 2016) guide to an development in feed intake, ADG and feed conversion ratio emulate with the control calves .The management of milk fermented with lactic acid bacteria to calves was evaluated by Maldonado et al. (2018); they found that calves fed with probiotic evidenced an improvement in nutritional parameters, body condition and weight gain.

Various lactic acid bacteria strains are oftentimes employed in farm animals as feed additives because they bearing probiotic features, so they can raise animal performance, enhance health and reduce the gravity of mucosal infection (Sandes et al., 2017).

\section{Effect of Lc. lactis on digestibility:}

Feeding LC-supplemented diet significantly increased digestibility of $\mathrm{CP}$, CF, EE and NFE than the control group; the results were illustrated in Table (4) and Fig (5).

Probiotics was reported to improve nutrient digestibility (Krehbiel et al., 2003; Abd El-Ghani, 2004), fibers degradation
(El-Waziry and Ibrahim, 2007) and rumen digestion (Kamel et al., 2004).

Haddad and Goussous (2005) have reported that supplementation with yeast culture (Diamond VRYC) in the diets of Awassi lambs had resulted in increased digestibility of dry matter (DM), organic matter (OM), crude protein (CP) and neutral detergent fiber (NDF). Whitley et al. (2009) have reported improved apparent digestibility of DM, CP, NDF and ADF in meat-goat given a diet with probiotics.

The addition of Bacillus licheniformis to the diet of lactating cows increased NDF digestibility (Qiao et al. 2010). Similarly, Boyd et al. (2011) found that lactating cows fed diets supplemented with Lactobacillus acidophilus and Propio-nibacterium freudenreichii had higher NDF and protein digestibility. Khalid et al. (2011) found that supplementing the diet of growing lambs with a commercial probiotic increased NDF and ADF digestibility. Similarly, a mixture of Lactobacillus probiotics increased digestibility of protein and fiber as well as increased microbial synthesis in growing goats (Galina et al. 2009).

\section{Effect of Lc. lactis on diarrhea.}

The effect of Lactococcus lactis on diarrhea presence and diarrhea period is illustrated in Fig (6). It was observed that diarrhea occurred on control calves more than calves that treated with Lactococcus lactis, and the duration of diarrhea at the same time was longer in control calves than with treated calves.

Le et al. (2016) presented that the administration of probiotic to young calves and they reported that diarrhea occurrence duration was 2 days less for the calves than the control. 
Effect of Lc. lactis on the number of E. coli in calves feces:

By microbiological examination for each calf's feces (7 calves in treated group and six calves in control group), it was observed as shown at Table (5) that the number of E.coli was more in control calves than in treated calves. This explains the incidence of diarrhea and increased duration of diarrhea in control calves than treated calves.

Lactic acid bacteria (LAB) are natural components of the normal intestinal microbiota in both humans and animals (Schneider et al., 2004) and have been used to inhabit the effects of pathogens such as Salmonella spp. (Gill et al., 2001) and Escherichia coli (Shu and Gill, 2002). These two pathogens are the most frequent bacterial etiologic agents in calf scours during the first week of life (Barrington et al., 2002; Millemann, 2009). Jozala et al. (2011) illustrate that, Lactococcus lactis can produce extracellular peptide, this peptide has been applied as a natural additive once it presents broad antibacterial activity.

Table (4): Nutrient digestibility (\%) as affected by dietary treatments Mean \pm SE

\begin{tabular}{|c|c|c|c|c|}
\hline \multirow{2}{*}{ Item } & \multicolumn{2}{|c|}{ Treatment* $^{*} \mathrm{P}<$} & \multirow{2}{*}{ Sig. } \\
\cline { 2 - 3 } & LC & CO & \multirow{2}{*}{ *** } \\
\hline CP & $69.35 \pm 1.23$ & $61.52 \pm .66$ & .005 & \multirow{2}{*}{ ** } \\
\hline CF & $54.10 \pm .79$ & $49.48 \pm .72$ & .013 & \multirow{2}{*}{$* * *$} \\
\hline EE & $74.07 \pm .51$ & $51.77 \pm 1.27$ & .005 & \multirow{2}{*}{ *** } \\
\hline NFE & $66.46 \pm 1.45$ & $50.69 \pm 1.89$ & .003 & \\
\hline
\end{tabular}

*Co, Control (un-supplemented); LC, treated ration (supplemented with LC. Lactis)

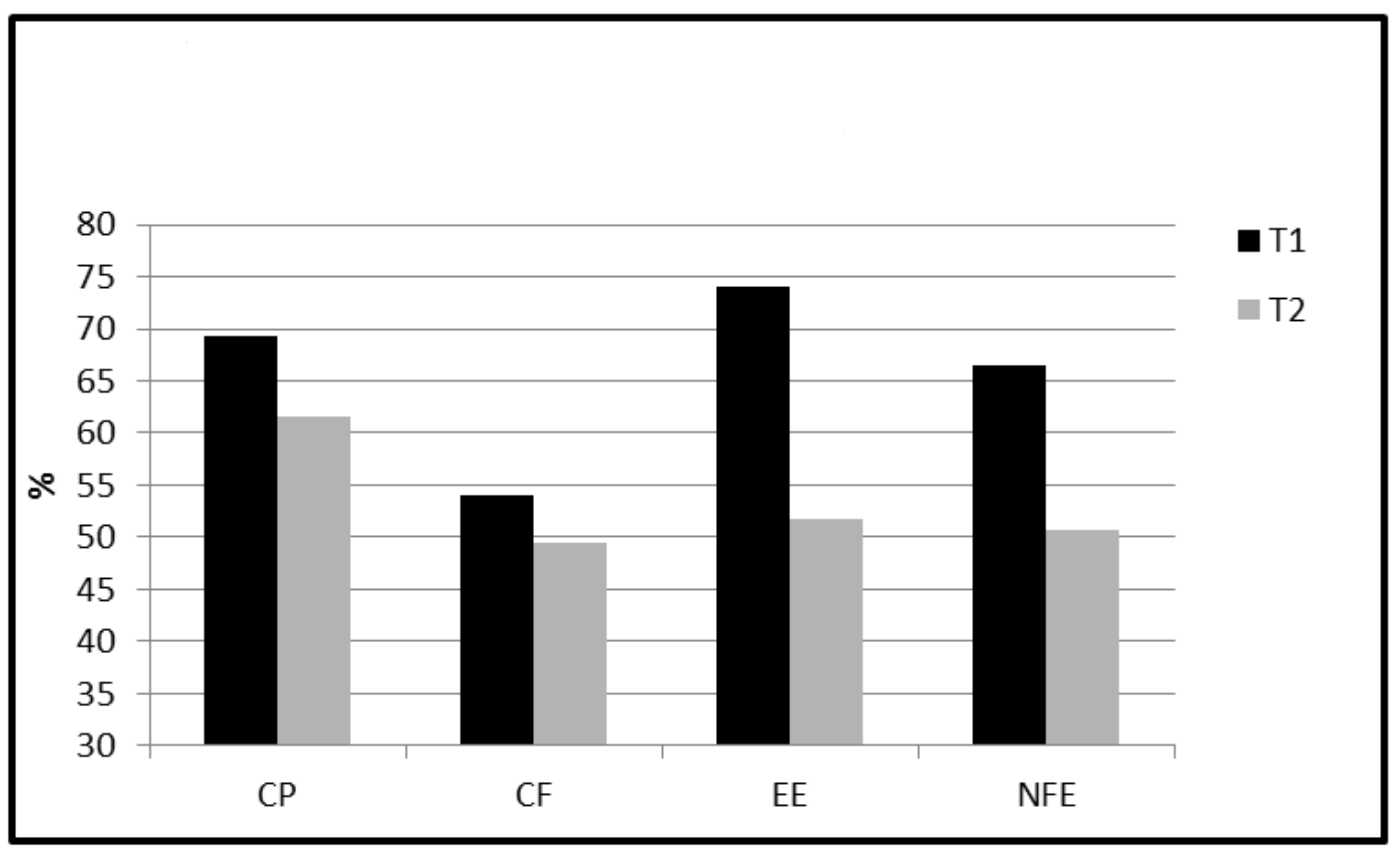

Fig. 5: Nutrient digestibility as affected by dietary treatments. 


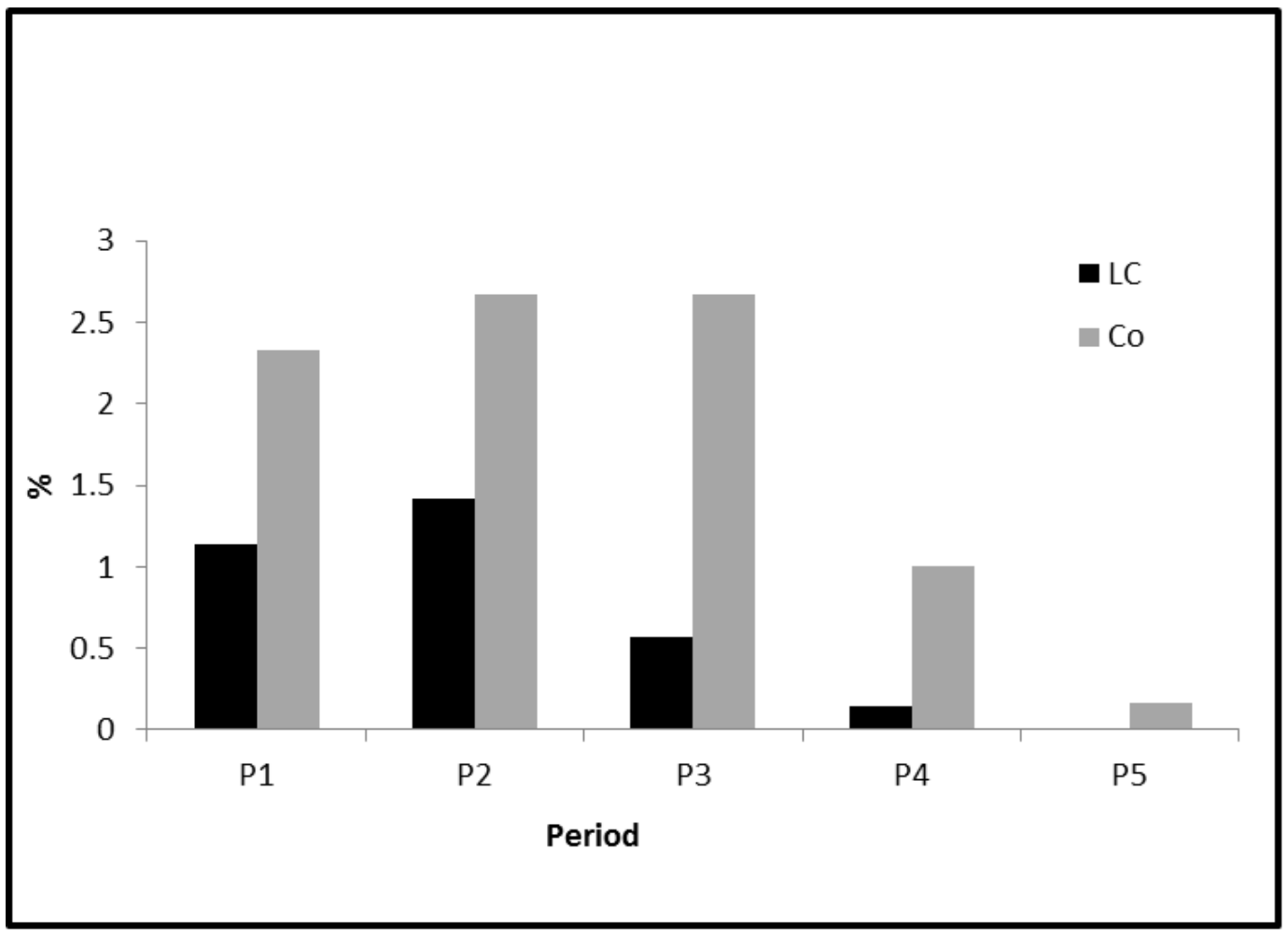

Fig. 6: Diarrhea incidence of calves as affected by LC.

Table 5: Effect of Lc.lactis on E. coli number in feces

\begin{tabular}{|l|c|}
\hline Treatment & E.coli number \\
\hline \multirow{4}{*}{ Lc. Lactis } & $2 \times 10^{3}$ \\
\cline { 2 - 2 } & $1.1 \times 10^{3}$ \\
\cline { 2 - 2 } & $2.2 \times 10^{3}$ \\
\cline { 2 - 2 } & $2 \times 10^{3}$ \\
\cline { 2 - 2 } & $2.3 \times 10^{4}$ \\
\cline { 2 - 2 } & $2.1 \times 10^{3}$ \\
\cline { 2 - 2 } & $2.4 \times 10^{3}$ \\
\hline \multirow{5}{*}{ Control } & $2 \times 10^{5}$ \\
\cline { 2 - 2 } & $2.8 \times 10^{5}$ \\
\cline { 2 - 2 } & $5.6 \times 10^{4}$ \\
\cline { 2 - 2 } & $4.6 \times 10^{5}$ \\
\cline { 2 - 2 } & $2.3 \times 10^{5}$ \\
\cline { 2 - 3 } & $8.4 \times 10^{4}$ \\
\hline
\end{tabular}


Effect of Lc. lactis on immunological parameters:

As shown in Table (6), it was observed that, the immunological parameters increased in treated calves than control calves, meaning that Lc. lactis promoted gut health via stimulation of the innate immune response, so treated calves immunity system produce larger amount of immunological parameters than control calves that have lower hygiene than treated calves. However, differences did not reach a significant level due to the less animal number used; also differences between animals within groups was higher than between treatments (the large standard error masked the difference between groups).

Immuno-modulatory effects of several strains of Lactococcus lactis have also been studied extensively under both in vitro and in vivo trials (Kitazawa et al., 1992; Kimoto et al., 2004). Kimoto et al. (2004) studied both in vitro as well as in vivo induction of cytokine production by strains of Lc. lactis. They achieved in vitro and in vivo trial on murine macrophage cell line $\mathbf{J 7 7 4 . 1}$ (as an APC) and spleen cells of experimental mice, respectively. On the basis of their study, they reported an increased level of cytokine production by various lactococcal strains tested. Among all the Lactococcal strains Lactococcus lactis subsp. Lactis $\mathrm{G} 50$ was found to induce the highest cytokine production.

Kitazawa et al. (1992) studied the effect of Lactococcus lactis subsp. cremoris KVS20 strain on mitogenic activity of B-cells. An increased proliferation of B-cells because of slime (phospho-polysaccharide consisting of rhamnose, glucose, galactose and phosphorus) produced by KVS20 strain was observed.

Probiotics may improve the immune system (Table 6) by stimulating antibody production, increasing epithelial barrier integrity, and up-regulating immune cells. Qadis et al. (2014b) found that supplementing calf feed with a probiotic mixture of Lactobacillus plantarum, Enterococcus faecium and Clostridium butyricum increased the number of leukocytes in both diarrheic and healthy calves and in the diarrheic calves the severity of diarrhea was also reduced. Probiotics can indirectly affect the ruminant's immune system by changing the microbe community. Kawakami et al. (2010) showed that Lactobacillus plantarum supplementation to Holstein Friesian calves increased the number of LAB which resulted in GIT-associated lymphoid and epithelial cells activating local immune responses in the intestine. Sun et al. (2010a) found that supplements of Bacillus subtilis fed to pre-weaned calves increased the levels of serum immunoglobulin G (IgG) and T helper cell 1 (Th1) cytokines such as interferon gamma (IFN-Y). In addition, Bacillus added to the diet of dairy calves with diarrhea promoted the activation and maturation of regulatory $\mathrm{T}$ cells (Novak et al., 2012).

Table (6): Effect of Lc.lactis on serum concentrations of IgA, IgG and Interleukne 2.

\begin{tabular}{|c|c|c|c|}
\hline Item & Control & Lc.lactis & Sig \\
\hline $\lg A(\mathrm{mg} / \mathrm{dl})$ & $107.6 \pm 8.68$ & $183 \pm 55.15$ & NS \\
\hline $\operatorname{lgG}(\mathrm{mg} / \mathrm{dl})$ & $1007.3 \pm 109.7$ & $1106.6 \pm 159.6$ & NS \\
\hline Interleukne 2 $(\mathrm{Pg} / \mathrm{ml})$ & $61.6 \pm 13.04$ & $72.8 \pm 9.5$ & NS \\
\hline
\end{tabular}


Probiotics offered to humans enhanced the immune response, reduced serum cholesterol levels and colon cancer, improved calcium absorption, vitamin synthesis, and lactose tolerance (Isolauri et al., 2001), as well as reduced diarrhea in children (Van Niel et al., 2002).

Various pathogens, alone or most often in combining with another pathogens, are etiologic agents of diarrhea in new born calves. Utmost of these agents are mainly transferred by the fecal oral path from the infected animals feces to the mouths of susceptible animals (Barrington et al., 2002). In young pre-weaned ruminants, where the rumen is not yet fully functional, the conventional target of probiotic application is to stabilize the GIT micro-biome to decrease the risk of pathogen colonization in the intestine and to facilitate a successful weaning. Further, Lee et al. (2005) found that probiotics enhance immune responses by proliferation of T-cell and B-cell, cytokine, immunoglobulin (IgA, IgE) production etc., which directly and indirectly help in the prevention of certain diseases like atopic eczema, AIDS, allergy (a hypersensitive reaction), etc. (Kimoto et al., 2007). Immunomodulatory effects of several strains of Lactococcus lactis have also been studied extensively under both in vitro and in vivo trials (Kimoto et al., 2004; Kitazawa et al., 1992). Kimoto et al. (2004) studied both in vitro as well as in vivo induction of cytokine production by strains of Lc. lactis.

\section{Conclusion}

Probiotic (Lactococcus lactis) supplementation generally improved average daily gain, nutrients digestibility, reduces the incidence of diarrhea, improve immunity status.

\section{REFERENCES}

Abd El-Ghani, A. A. (2004). Influence of diet supplementation with yeas culture (Saccharomyces cerevisiae) on performance of Zaraibi goats. Small Rumin Res 52: 223-229.

Antunovic, Z., M. Speranda, B. Liker, V. Seric, D. Sencic, M. Domacinovic and T. Speranda (2005). Influence of feeding the probiotic Pioneer PDFMR to growing lambs on performances and blood composition. Acta Vet (Beograd) 55: 287-300.

Antunovic, Z., M. Speranda, D. Amidzic, V. Seric, Z. Steiner, N. Domacinovic and F. Boli. (2006). Probiotic application in lambs nutrition. Krmiva $.48:$ 175-180.

Barrington, G. M., J. M. Gay and J. F. Evermann (2002). Biosecurity for neonatal gastrointestinal diseases. Veterinary Clinics of North America. Food Animal Practice 18: 7-34.

Boyd, J., J.W. West and J.K. Bernard (2011). Effects of the addition of direct-fed microbials and glycerol to the diet of lactating dairy cows on milk yield and apparent efficiency of yield. Journal of Dairy Science .94: 46164622.

Desnoyers, M., S. Giger-Reverdin, G. Bertin, C. Duvaux-Ponter and D. Sauvant (2009). Meta-analysis of the influence of Saccharomyces cerevisiae supplementation on ruminal parameters and milk production of ruminants. J Dairy Sci 92: 1620-1632.

El-Waziry A. and H. R. Ibrahim (2007). Effect of Saccharomyces cerevisiae of yeast on fiber digestion sheep fed Berseem (Trifolium alexandrinum) hay and cellulose activity. Aust $\mathrm{J}$ Basic Appl Sci 1: 379-385.

Fahey, J.L. and E.M. McKelvey (1965). Quantitative determination of serum immunoglobulins in antibody-agar plates. J. Immunol., 94:84-90. 
Fuller, R. (1989). A review: Probiotics in man and animals. J. Appl. Bacteriol. 66: 365- 378.

Galina, M. A., M. A. Ortiz-Rubio, M. Delgado-Pertinez and L. J. Pineda (2009). Goat kid's growth improvement with a lactic probiotic fed on a standard base diet. Options Mesditerranéennes 85: 315-323.

Gill, H. S., Q. Shu, H. Lin, K. J. Rutherfurd and M. L. Cross (2001). Protection against translocating Salmonella typhimurium infection in mice by feeding the immune-enhancing probiotic Lactobacillus rhamnosus strain HN001. Medical Microbiology and Immunology 190: 97-104.

Grahn, E., S. E. Holm, H. Lilja and K. Sellgren (1994). Interference of a Lactococcus lactis strain on the human gut flora and its capacity to pass the stomach and intestine. Scandinavian Journal of Nutrition 38: 2-4.

Gruzza, M., Y. Duval-Iflah and R. Ducluzeau (1992). Colonization of the digestive tract of germ-free mice by genetically engineered strains of Lactococcus lactis: study of recombinant DNA stability. Microbial Releases 1: 165-171.

Guo, X., D. Li, W. Lu, X. Piao and X. Chen (2006). Screening of Bacillus strains as potential probiotics and subsequent confirmation of the in vivo effectiveness of Bacillus subtilis MA139 in pigs. Antonie Van Leeuwenhoek.90(2):139-146.

Haddad, S. G. and S. N. Goussous (2005). Effect of yeast culture supplementation on nutrient intake, digestibility and growth performance of Awassi lambs. Anim Feed Sci Techn 118: 343-348.

Hulbert and Ballou (2012). Innate immune responses and health of individually reared Holstein calves after placement into transition-pens 23 d after weaning. J. Dairy Res. 79:333-340.
Hussein, A. F. (2014). Effect of biological additives on growth indices and physiological responses of weaned Najdi ram lambs. J Exp Biol Agr Sci 2: 597- 607.

Isolauri, E., Y. Sutas, P. Kankaanpaa, H. Arvilommi and S. Salminen (2001). Probiotics: effects on immunity. Am. J. Clin. Nutr. 73(Suppl. 2):444-450.

Jang, Y. D., H. K. Oh, L.G. Piao, H. B. Choi, J. H. Yun and Y.Y. Kim (2009). Evaluation of Probiotics as an Alternative to Antibiotic on Growth Performance, Nutrient Digestibility, Occurrence of Diarrhea and Immune Response in Weaning Pigs. J Anim Sci Techn 51: 25-32.

Jozala, A. F., D. P. Silva, A. A. Vicente, J. A. Teixeira, A. P. Júnior and T. C. V. Penna (2011). Processing of byproducts to improve nisin production by Lactococcus lactis. African Journal of Biotechnology Vol. 10(66):14920-14925.

Kamel, H. E., J. Sekine, A. M. El-Waziry and M. H. Yacout (2004). Effect of Saccharomyces cerevisiae on the synchronization of organic matter and nitrogen degradation kinetics and microbial nitrogen synthesis in sheep fed Barseem hay (Trifolium alexandrium). Small Rumin Res 52: 211-216.

Kawakami, S-I., T. Yamada, N. Nakanishi, Y. Cai and H. Ishizaki (2010). Leukocyte phagocytic activity with or without probiotics in Holstein calves. Research Journal of Biological Sciences. 5: 13-16.

Kearl, L. C. (1982). Nutrient Requirements of Ruminants in Developing countries. International Feedstuff Institute, Utah Agricultural Experiment Station, Utah State University, Logan, Utah, USA.

Khalid, M. F., S. Muhammad, Mahr-UnNisa and Zia-Ur-Rehman (2011). Response of growing lambs fed on different vegetable protein sources with or without probiotics. 
International Journal of Agriculture and Biology 13: 332-338.

Kimoto, H., K. Mizumachi, N. Masaru, K. Miho, F. Yasuhito, T. Okamoto, S. Ichirou, M. T. Noriko, J. Kurisaki and O. Sadahiro (2007). Lactococcus sp. As Potential Probiotic Lactic Acid Bacteria. Japan Agricultural Research Quarterly 41: 181-189.

Kimoto, H., K. Mizumachi, T. Okamoto and J. Kurisaki (2004). New Lactococcus strain with immunomodulatory activity: enhancement of Th1-type immune response. Microbiology Immunology 48: 75-82.

Kimoto, H., M. Nomura, M. Kobayashi, T. Okamoto and S. Ohmomo (2004). Identification and Probiotic Characteristics of Lactococcus Strains from Plant Materials. Animal Science Technology (Japan) 38: 111117.

Kitazawa, H., T. Yamaguchi and T. Itoh. (1992). B-cell mitogenic activity of slime products produced from slimeforming, encapsulated Lactococcus lactis ssp. cremoris. Journal of Dairy Science 75: 2946-2950.

Klijn, N., A. H. Weerkamp and W. M. de Vos (1995b). Genetic marking of Lactococcus lactis shows its survival in the human gastrointestinal tract. Applied and Environmental Microbiology 61: 2771-2774.

Krehbiel, C. R., S. R. Rust, G. Zhang and S. E. Gilliland (2003) Bacterial directfed microbials in ruminant diets: Performance response and mode of action. J Anim Sci 81 (Suppl 2): 120132.

Larson, L. L., F. G. Owen, J. L. Albright, R. D. Appleman, R. C. Lamb and L. D. Muller (1977). Guidelines Toward More Uniformity in Measuring and Reporting Calf 57 Experimental Data.Journal of Dairy Science (Vol. 60). Elsevier. https://doi.org/ 10.3168/ jds. S0022-0302(77)83975-1
Le, O. T., P. J. Dart, K. Harper, D. Zhang, B. Schofield, M. J. Callaghan, A. T. Lisle, A. V. Klieve and D. M. McNeill (2016). Effect of probiotic Bacillus amyloliquefaciens strain H57 on productivity and the incidence of diarrhoea in dairy calves. Animal Production Science 57(5) 912-919.

Lee, W. K. (2005). Hypocholesterolemic effect of Lactococcus lactis subsp. lactis biovar diacetylactis N7 and Lactococcus lactis subsp. lactis 527 strains in SD rats. Bioscience Microflora 24: 11-16.

Lilley, D. M. and R. H. Stillwell. (1965). Probiotics: Growth promoting factors produced by microorganisms. Science. 147: 747-748.

Maldonado, N. C., J. Chiaraviglio, E. Bru, L. De Chazal, V. Santos and M. E. F. Nader-Macías (2018). Effect of Milk Fermented with Lactic Acid Bacteria on Diarrheal Incidence, Growth Performance and Microbiological and Blood Profiles of Newborn Dairy Calves. Probiotics \& Antimicro. 10:668-676.

Mancini, G., A.O. Carbonara and J.F. Heremans (1965). Immunochemical quantitation of antigens by single radial immunodiffusion. Immuno.chem., 2:235-254.

Metchnikoff, E. (1907). Prolongation of Life. G. P. Putnam and Sons, New York.

Millemann, Y. (2009). Diagnosis of neonatal calf diarrhoea. Revue de Medecine Veterinaire 160, 404-409.

Novak, K. N., E. Davis, C.A. Wehnes, D. R. Shields, J. A. Coalson, A. H. Smith and T. G. Rehberger (2012). Effect of supplementation with an electrolyte containing a Bacillus-based direct-fed microbial on immune development in dairy calves. Research in Veterinary Science. 92: 427-434.

Qadis, A. Q., S. Goya, V. Yatsu, A. Kimura, T. Ichijo and S. Sato (2014b). Immune-Stimulatory Effects of a 
Bacteria-Based Probiotic on Peripheral Leukocyte Subpopulations and Cytokine mRNAExpression Levels in Scouring Holstein Calves. The Journal of Veterinary Medical Science. 76:677-684.

Qiao, G. H., A. S. Shan, N. Ma, Q. Q. Ma and Z. W. Sun. (2010). Effect of supplemental Bacillus cultures on rumen fermentation and milk yield in Chinese Holstein cows. Journal of Animal Physiology and Animal Nutrition 94: 429-436.

Salak-Johnson, J. L. and J. J. McGlone (2014). Making sense of apparently conflicting data: Stress and immunity in swine and cattle. J. Anim. Sci. 85:81-88.

Sandes, S., L. Alvim, B. Silva, L. Acurcio, C. Santos, M. Campos, C. Santos, J. Nicoli, E. Neumann and Á. Nunes (2017). Selection of new lactic acid bacteria strains bearing probiotic features from mucosal microbiota of healthy calves: Looking for immunobiotics through in vitro and in vivo approaches for immunoprophylaxis applications. Microbiological Research. Volume 200 : 1-13.

Schneider, R., M. R. Rosmini, M. Hermann and R. Vogel. (2004). Identificaci $n$ de bacterias IJcticas componentes de la microbiota tيpica de los terneros criados en condiciones artificiales.
Revista FAVE - Secci n Ciencias Veterinarias 3: 7-15.

Shu, Q., and H. S. Gill (2002). Immune protection mediated by the probiotic Lactobacillus rhamnosus HN001 (DR20 ${ }^{\mathrm{TM}}$ ) against Escherichia coli 0157:H7 infection in mice. FEMS Immunology and Medical Microbiology 34: 59-64.

SPSS (Statistical Package for Social Science) program version 19.0, (2010).

Sun, P., J. Q. Wang and H. T. Zhang (2010a). Effects of Bacillus subtilis natto on performance and immune function of preweaning calves. Journal of Dairy Science 93: 58515855.

Teuber, M., A. Geis and H. Neve (1992). The genus Lactococcus. In: The Prokaryotes, Vol. II, 2nd edn (eds. Balows, A., Truber, H.G. Dworkin, M. Harder, W. and Schleifer, K.H.). Springer Verlag, New York, pp. 14821501.

Van Niel, C. W., C. Feudtner, M. M. Garrison and D. A. Christakis (2002). Lactobacillus therapy for acute infectious diarrhea in children: a metaanalysis. Pediatrics. 109(4): 678-684.

Whitley, N. C., D. Cazac, B. J. Rude, D. Jackson-O'Brien and S. Parveen (2009). Use of commercial probiotics supplement in meat goats. J Anim Sci . 87: 723-728. 
تأثير بكتريا الاكتوكوكاس لاكتس كمصدر للبربيوتك على الأداء والحالة المناعية

\section{للعجول الرضيعة}

أسامة ابوالعز محمد نايل ، جمال أحمد براغيت ، بركات محمد أحمد ، محمود أحمد المشطاوى قسم الانتاج الحيوانى - كلية الززاعة - جامعة المنوفية برات

الملخص العربى

أجريت هذه الدراسة على العجول الرضيعة بمزرعة الجاموس ومعمل تغذية الحيوان بقسم الانتاج الحيوانى بكلية الزراعة جامعة المنوفية. بهدف معرفة تأثير بكتيريا اللاكتوكوكاس لاكتيس كمصدر للبروبيوتيك على الجادئ الاداء الإنتاجي

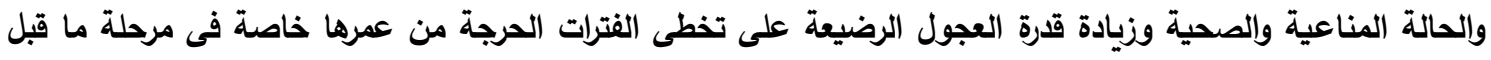

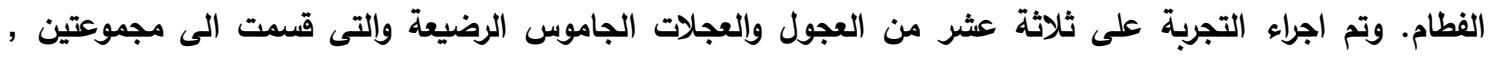

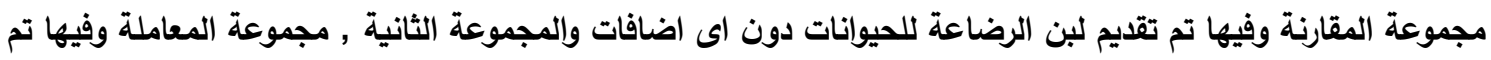

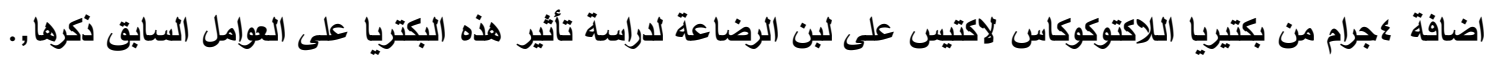

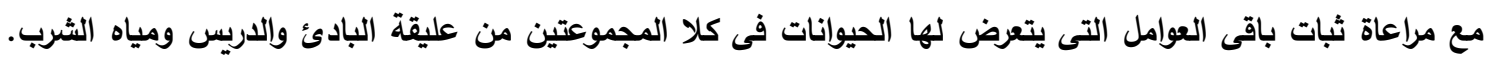

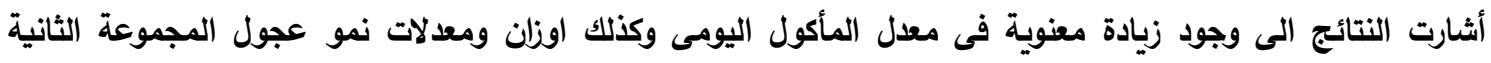

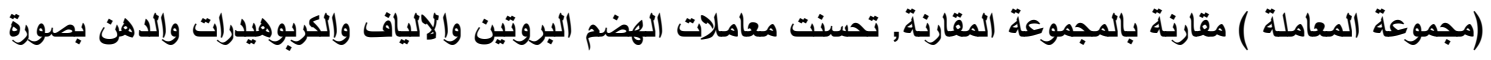

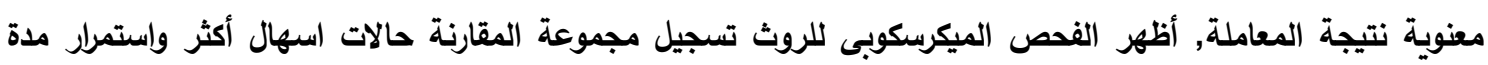

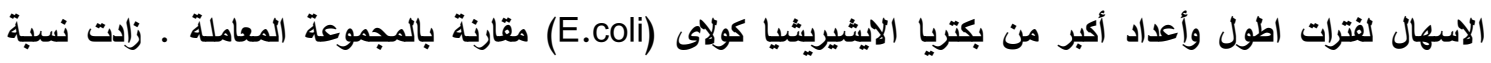

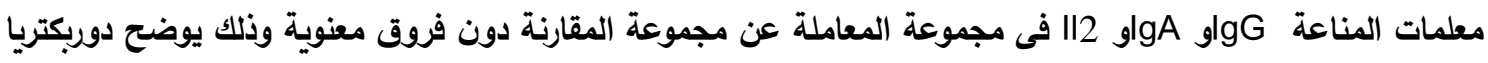
اللاكتوكوكاس لاكتس فى تحسين نظام المناعة فى المجموعة المعاملة من خلال تحفيزها للجهاز المناعى بها وافرازه لكميات اكبر من هذه المعلمات المناعية. 